\title{
PERAN AL WARAQ DALAM INDUSRI PENERBITAN BUKU ISLAM DAN DAMPAKNYA TERHADAP PERKEMBANGAN KEILMUAN ISLAM
}

\author{
Budhi Santoso \\ Prodi Ilmu Perpustakaan UIN Raden Fatah \\ Email : kangbudhi_uin@radenfatah.ac.id
}

\begin{abstract}
Introduction. This article discusses intellectual development in the Islamic world and the role of al-Waraq in the Islamic book publishing industry.

Data Collection Method. The method used in this article is the literature study method used in obtaining data.

Analysis Data. The data obtained is then grouped according to relevance to the formulation of the problem

Results and Discussions. The copying of scientific texts is very instrumental in the spread of knowledge, besides being a copyist of the Al Warraq manuscript, it also acts as editor and publisher of books. that. With the existence of this catalog, we can find out the number of publications at the time and as literature for the study of Muslim works in the golden era. Copyright licenses are issued to avoid plagiarism or recognition of a work by Al Warraq. The Al Warraq profession was slowly displaced by the discovery of printing technology in the fifteenth century.
\end{abstract}

Keyword: al warraq, Islamic scientific development, Islamic Book Publishing Indusrial

\section{A. PENDAHULUAN}

Islam sangat menghargai ilmu pengetahuan, Ilmu pengetahuan menempati kedudukan yang sangat penting dalam ajaran islam, hal ini terlihat dari banyaknya ayat al-qur'an yang memandang orang berilmu dalam posisi yang tinggi dan mulia disamping hadis-hadis nabi yang banyak memberi dorongan bagi umatnya untuk terus menuntut ilmu.

Didalam al qur'an, kata ilmu terulang sebanyak 854 kali, ini bermakna bahwa ajaran Islam sebagaimana tercermin dari al-qur'an sangat kental dengan nuansa nuansa yang berkaitan dengan ilmu, sehingga dapat menjadi ciri penting dari agama Islam. Orang berilmu dalam agama islam memiliki derajat yang tinggi seperti dalam suarat Al Mujadalah ayat 11 yang artinya :

"Allah meninggikan beberapa derajat (tingkatan) orang-orang yang berirman diantara kamu dan orang-orang yang berilmu (diberi ilmu pengetahuan). Dan Allah maha mengetahui apa yang kamu kerjakan".

Dari pemaparan diatas umat islam sejak dulu sudah akrab dengan kegiatan keilmuan seperti membaca, menulis dan menyalin, misalnya para sahabat menuliskan ayat al-quran dan hadits dalam tulang dan pelepah kurma. Kemudian dengan berkembangnya 
pengetahuan dan produksi kertas munculah profesi baru dalam khasanah islam. Profesi tersebut dinamakan warraq atau penyalin naskah atau buku. Dalam menyalin buku warraq mempunyai beberapa motivasi yaitu keilmuan, ibadah, sosial, politik dan ekonomomi. Dalam artikel ini penulis akan membahas tentang bagaimanakah peran penting profesi al waraq dalam indusri penerbitan buku islam dan dampaknya terhadap perkembangan keilmuan.

\section{B. METODE PENELITIAN}

Sebuah penelitian ilmiah harus menggunakan teknik penyusunan yang sistematis untuk memudahkan langkah-langkah yang akan diambil. Dalam penelitian ini penulis menggunakan studi literatur pada buku-buku yang membahas tentang perkembangan kebudayaan islam, jurnal, dan penelitian yang telah dilakukan yang berkaitan dengan perkembangan kebudayaan islam. Output dari studi literatur ini adalah terkoleksinya referensi yang relefan dengan perumusan masalah.

\section{HASIL DAN PEMBAHASAN}

\section{Profesi al-warraq}

Seseorang yang berprofesi sebagai penyalin disebut Al- Warraq. (dari kata warraq, waraga, "lembaran" ) dan sebagai pencatat ia disebut nassakh. ${ }^{1}$ Al-Warraq atau warraq adalah pekerjaan penyalin buku yang dilakukan oleh sebagian masyarakat muslim pada masa klasik (Agus Rifai, 2013; 174). ${ }^{2}$ Sebagai seorang penyalin, warraq mempunyai kedudukan yang penting sehingga banyak ilmuwan serta sastrawan selalu melekatkan nama Warraq dibelakang nama pengarang.

A. Dalam menjalankan profesinya warraq dibagi menjadi tiga jenis :

a. warraq paruh waktu (parttime)

Warraq partime adalah warraq yang bekerja bekerja berdasarkan pesanan kemudian di berikan upah sesuai pekerjaannya.

b. warraq yang bekerja pada orang kaya, pejabat dan ulama

Jenis warraq ini mendapatkan gaji bulanan, salah satu warraq yang berkerja pada orang kaya, pejabat dan ulama adalah Khalid Ibn Abi Hajjaj, hidup dibawah

\footnotetext{
1 J Pedersen, The Arabic Book diterjemahkan Alwiyah Abdurrahman, "Fajar Intelektualisme Islam, Buku dan Sejarah Penyebaran Informasi di dunia Arab", Bandung : Bina IImu, 1996 HIm 64

${ }^{2}$ Agus Rifai, Perpustakaan Islam : Konsep, Sejarah dan Kontribusinya dalam Membangun Peradaban Islam Masa Kelasik. Jakarta : PT Raja Grafindo Persada,2013 HIm 174
} 
Tamaddun: Jurnal Kebudayaan dan Sastra Islam, Vol. 19 No. 1, Juni 2019 (63-69) pemerintahan Umayyah caliph walid I, sebagai penyalin khalid mempunyai tulisan yang bagus sehingga banyak dicari orang. Ibnu Nadim mempunyai pendapat tersendiri tentang Khalid Ibn Abi Hajjaj, yaitu khalid pernah menulis kitab di Masjid Nabawi dengan tinta emas surat as syam.

c. Warraq yang tidak memiliki kemandirian

Disebut Warraq yang tidak memiliki kemandirian karena warraq ini adalah seorang budak yang tidak mempunyai kebebasan, seorang budak akan bernilai tinggi jika dia mampu untuk menyalin naskah, karena itu dalam perkembangannya budak di jual di pasar kemudian di percikan tinta dibajunya dan di tangannya supaya terkesan dia bisa menulis dan menyalin naskah sehingga harganya mahal.

B. Kegiatan profesi al-warraq

\section{Penyalinan naskah}

Para warraq mendapatkan naskah yang akan disalin langsung dari para ulama. Biasanya ulama mengajar atau membedah karya tulisnya di masjid-masjid. maka bila ingin menyalin sebuah kitab para warraq harus hadir dalam dalam kajian para ulama di masjid. namun ada juga para warraq yang datang langsung ke rumah para ulama untuk menyalin kitab. ulama yang didatangi akan mendiktekan naskah bukunya kepada warraq

\section{Percetakan dan Penjualan}

Al-Syaubi yang tinggal di Baghdad pada awal kesembilan di bawah pemerintahan Harun Al-Rasyid dan Al-Ma'mun, selain bekerja sebagai warraq beliau juga memiliki kios tempat menjual buku.

C. Tokoh al-warraq

Diantara Warraq yang terkenal pada waktu itu ialah al-Saubi, karena buku-buku yang disalin olehnya sangat bermutu, akurat, tulisannya indah dan bagus.

Ibn Al- Nadim juga mencatat nama dua orang warraq, Al-Mubarrad dan Al-Jahiz yang menulis tentang risalah manfaat warraq dan kerugian-kerugiannya.

Al-Bahhatie yang hidup di abad kesebelas, ia telah menyalin sebuah buku mengenai Hadits Rasulullah . Ibn Al-Nadim penulis Fihrist, menuli sebuah penelitian tentang bahasa Arab dan karya-karya sastra dari para pengarang terkenal yang dahulunya adalah seorang Warraq.

Tokoh warraq lainnya adalah Yaqut (pada mulanya adalah seorang budak yang telah dibebaskan pada tahun 1200) dan bekerja sebagai pencatat (nassakh) untuk 
mendapatkan nafkah, ia mengisahkan tentang Muhammad ibn Sulayman yakni seorang hartawan yang menghamburkan semua kekayaannya. Sehingga yaqut harus menjadi seorang penyalin untuk mendapatkan penghasilan, sampai ia mendapatkan pekerjaan yang baru.

Kebanyakan para penyalin bekerja untuk para pengarang ataupun pejabat tinggi, serta orang-orang kaya yang ingin membangun perpustakaan. Hal itu terjadi pada masa awal pemerintahan Dinasti Abbasiah, sekitar tahun 800, yakni ketika gerakan penulisan mulai memperoleh momentum dan kegiatan penerjemnahan literatur kuno mulai digiatkan. Terutama di akademi Al-Ma'mun yang baru, Bayt AlHikmah di Bagdad. Dan sejumlah besar penyalin dipekerjakan di sini.

D. Peran dan dampak pada keilmuan

Sebelum adanya mesin cetak seperti sekarang, penggandaan melalui penyalinan naskah menjadi aktivitas penting dalam penyebaran keilmuan, semakin banyak warraq menyalin naskah makan akan menjadi prestasi tersendiri bagi profesi alwarraq. Peranan yang tidak kalah pentingnya pada masa khalifah Harun al-Rasyid, dalam proses demoktratisasi pengetahuan dan pengembangan perpustakaan pada saat itu juga berada ditangan Warraq (penyalin naskah). Pekerjaan seorang Warraq sangat kompleks, disamping sebagai penyalin naskah mereka juga seorang penjual buku. Disamping bekerja sebagai penyalin naskah dia juga bekerja sebagai pencari naskah dan sekaligus meminta izin kepada para pengarang buku untuk menyalin naskah karya mereka. Diantara Warraq yang terkenal pada waktu itu ialah Penyalin (warraq) adalah juga garis penyambung antara sastrawan/ilmuwan dan masyarakat umum. Sebetulnya mereka juga tergolong kepada sastrawan, tetapi kehidupan mereka tergantung pada pelipatgandaan karya-karya para penulis. Mereka juga penjual buku. Seorang warraq mempunyai kios/toko (hanut, dukkan) dimana pelaksanaan penulisan dan perdagangan buku berlangsung. Oleh sebab itu warraq mempunyai rasa dibutuhkan, baik sebagai wakil dunia pendidikan maupun pengusaha yang merdeka. Walaupun dia sebenarnya melaksanakan sejumlah pekerjaan didalam kiosnya sendiri, adalah hal yang lazim jika ia juga pergi bekerja pada orang lain untuk mendapatkan uang.

Buku-buku yang ditulis para warraq diterbitkan karena pesanan atau untuk dijual dipasar bebas. Untuk tujuan ini ia harus mendapatkan buku-buku tersebut dengan cara membelinya untuk dijual kembali. Setiap orang yang menginginkan karya tertentu akan datang kepada warraq dan memintanya untuk mencari buku tersebut. 
Tamaddun: Jurnal Kebudayaan dan Sastra Islam, Vol. 19 No. 1, Juni 2019 (63-69)

Penjualan buku dulakukan seperti perdagangan yang lain, pembeli dan penjual melakukan tawar menawar untuk sebuah buku seperti yang masih terjadi sampai sekarang. Kadang-kadang penjualan buku dengan cara lelang (nida', “seruan”). Kios-kios buku bermunculan dimana-mana, sehingga mereka menempati daerah yang sangat luas dikota-kota yang disebutnya juga dengan pojok buku atau pojok warraq di bagdad.

Seorang warraq independen melakukan tugas yang dizaman kita dibagi antara percetakan dan penjual buku, dan juga dapt kita tambahkan yakni perusahaan penerbitan. Warraq yang bekerja pada seorang pengarang, yang mempunyai salinan pertama dari sebuah buku yang dutulisnya, adalah orang yang harus didekati oleh siapa saja yang menginginkan buku tersebut. Dalam sejarah juga dikatakan seorang warraq yang hidup pada pertengahan abad ke sepuluh menceritakan bahwa pada suatu hari ia sedang berpapasan dengan penyair Al-Nasyi'i yang berkata kepadanya, bahwa dia telah menciptakan sebuah qasidah (syair panjang dengan aturan tertentu) yang dinanti-nanti orang pada saat itu, dan dia menyuruh seorang warraq menuliskannya dengan tangannya sendiri supaya dapat diterbitkan dan dibawa ke toko buku oleh para warraq. Namun itu tidak berarti ia memperoleh hak penerbitan atas karya tersebut, selain dari salinan yang dibeli atau diterbitkannya sendiri.

Pada tahun 978 H munculah Ibnu Nadim, selain berprofesi sebagai warraq, beliau juga menjadi seorang pustakawan dan penjual buku yang kemudian menulis sebuah karya besar berupa katalog berjudul al-Fihrist yang diakui oleh kalangan akademisi dan ilmuan sebagai karya yang sangat baik. ${ }^{3}$ Pembuatan katalog berjudul al-Fihrist dan merupakan suatu karyabesar yang berisi bibliografi Islam yang menggambarkan perkembangan Islam dan terbitan naskah serta artikel berdasarkan kajian terhadap literatur yang terbit di dunia Muslim. Data yang dicatat dalam bibliografi antara lain adalah nama pengarang, nama penyunting, judul pustaka, tempat terbit, penerbit, tahun terbit dan edisi, volume, nomor, halaman (untuk majalah), serta keterangan fisik dokumen pustaka tersebut, misalnya jumlah halaman, tinggi buku, ilustrasi dan sebagainya Kitab Al-Fihrist yang ditulis Ibnu al-Nadim tidak hanya menggambarkan apa yang pernah dicapai atau dipahami seseorang terhadap materi Islam, akan tetapi juga menggambarkan bagaimana umat

\footnotetext{
${ }^{3}$ Phillip K. Hitti, History Of The Arabs, Jakarta : Serambi, 2006 hlm 521
} 
Islam bersentuhan dengan dunia atau paham dan keyakinan lain yang tertuang di dalam suatu literatur sebagai karya orang Islam. ${ }^{4}$

\section{Lisensi dan Perlindungan Hak Cipta}

Pada masa awal kegiatan penyalinan naskah, banyak al-warraq yang melakukan kecurangan yaitu menerbitkan sendiri dan mengakui karya yang disalinnya sebagai karnyanya. Oleh karena itu, untuk menghindari plagiasi dan perlindungan hak cipta dibuatlah sebuah aturan yaitu sebuah naskah yang disalin warraq tidak bernilai sebelum mendapat ijazah dari pengarang. Proses untuk memperoleh ijazah ini sangat lama dan berbelit-belit.

Seorang warraq harus membaca kembali naskah salinannya sampai 3 kali, dan setiap kali pembacaan, pengarang biasanya memberikan catatan baru, komentar atau atau tambahan keterangan, baru apabila pengarang sudah puas, sang Warraq mendapatkan ijazah/pengakuan, dan dia sudah berhak menerbitkan naskah itu dalam bentuk buku. Disamping itu Ijazah berperan pula sebagai tanda untuk memperoleh izin untuk menyalin sebuah karya. Namun tidak berarti seorang pemegang ijazah mempunyai hak cipta.

Apabila seorang pengarang meninggal dunia, maka salinan naskah yang dibuat oleh Warraq harus dibacakan terlebih dahulu dihadapan seorang pakar dan seorang pakar akan memperoleh royalti untuk jasanya itu, dan dia juga berhak memberikan ijazah untuk naskah yang disalin si Warraq.

\section{Berakhirnya Profesi warraq}

Ketika alat cetak buku mulai dipergunakan di Eropa pada pertengahan abad kelima belas. Sejumlah buku Islam pun mulai diterbitkan dalam bentuk tercetak dan tentu saja menggeser peran Warraq .

Dengan hadirnya mesin cetak, maka tugas penyalinan telah diganti oleh mesin cetak ini walaupun pekerjaan warraq belum punah benar karena para ilmuwan Eropa dan Timur masih sering membutuhkan jasa mereka melalui karya manuskrip para warraq.

Di jaman sekarang tugas penyalin telah digantikan oleh mesin cetak, namun perdagangan buku masih berlanjut seperti sedia kala, dan penjual buku adalah penerus kaum warraq di masa yang lalu, saat ini untuk menemui warraq sudah sangat susah, hanya di daerah-daerah terpencil lah orang dapat berjumpa dengan

\footnotetext{
${ }^{4}$ Republika, Kitab Al-Fihrist, Bibliografi Terbesar Sepanjang Masa, dalam http://goo.gl/v3oll4
} 
Tamaddun: Jurnal Kebudayaan dan Sastra Islam, Vol. 19 No. 1, Juni 2019 (63-69) penyalin-penyalin gaya kuno ini. ${ }^{5}$

\section{KESIMPULAN}

Profesi menyalin naskah keilmuan berperan sangat penting dalam penyebaran ilmu pengetahuan, Penyalin naskah atau Warraq adalah berperan sebagai editor dan penerbit buku. Karya terbesar warraq adalah diterbitkannya sebuah katalog al-fihrist oleh Ibnu Nadim berisi tentang bibliografi tebitan naskah dan artikel yang dibuat oleh penulis saat itu. Dengan adanya katalog tersebut dapat diketahui jumlah terbitan saat itu dan sebagai literatur untuk kajian karya umat Islam di era keemasan.

Pada masa awal kegiatan penyalinan naskah, banyak al-warraq yang melakukan kecurangan yaitu menerbitkan sendiri dan mengakui karya yang disalinnya sebagai karnyanya. Oleh karena itu dibuatlah aturan berupa lisensi ijasah bagi al warraq untuk menghindari plagiasi dan perlindungan hak cipta.

Ditemukannya mesin cetak di Eropa pada awal abad ke lima belas pelan-pelan menggeser peran al warraq dalam menyalin naskah, menjadi awal berakhirnya masa al-warraq. saat ini untuk menemui warraq sudah sangat susah, hanya di daerah-daerah terpencil lah orang dapat berjumpa dengan penyalin-penyalin gaya kuno ini.

\section{DAFTAR PUSTAKA}

Agus, Rifai, Perpustakaan Islam : Konsep, Sejarah dan Kontribusinya dalam Membangun Peradaban Islam Masa Kelasik. Jakarta : PT Raja Grafindo Persada, 2013

Hitti, Phillip K, History Of The Arabs, Jakarta : Serambi, 2006

Pedersen,J, The Arabic Book diterjemahkan Alwiyah Abdurrahman , "Fajar Intelektualisme Islam, Buku dan Sejarah Penyebaran Informasi di dunia Arab", Bandung : Bina Ilmu, 1996

Republika, Kitab Al-Fihrist, Bibliografi Terbesar Sepanjang Masa, dalam http://goo.gl/v3oII4 diakses tanggal 15 Mei 2019

\footnotetext{
${ }^{5}$ J Pedersen, The Arabic Book diterjemahkan Alwiyah Abdurrahman, "Fajar Intelektualisme Islam, Buku dan Sejarah Penyebaran Informasi di dunia Arab", Bandung : Bina IImu, 1996 HIm 77 